\title{
Non-Litigation Process Land Dispute Settlement for Legal Certainty \\ Teddy Chandra
}

\author{
Faculty of Law, Maranatha Christian University
}

email: notteddychandra@yahoo.co.id

\begin{abstract}
The purpose of this study is to try to make the legal instruments for land use hold land disputes over land disputes. The research method used in research responsibilities is normative juridical. The results of this study suggest that land disputes that are formed are multi-dimensional and complex covering legal, economic, political, and social culture, national defense needs. Land administration is very important to reduce land disputes by following the land suitability regulations with article 19 paragraph (2) letter $c$ of the UUPA Land certificates form public administration products, if disputes occur in the future, land dispute resolution and non-litigation land dispute resolution can be resolved. The part of the government that actively participates in the community helps to make an important contribution to public administration in Indonesia with land disputes and non-litigation process. This model of law enforcement seeks to realize legal certainty in order to create a sense of security, peace and harmony, the impact of order will encourage people to try and work well as an effort to improve the quality of their lives. This article finally looks at the development of law by means of harmonizing values to overcome the problem solving that does not exist, which is damaged or wrong, which is still lacking, congestion, and deterioration or a deterioration in circumstances. Win-win solutions are still strong enough and efficient to empower legal energy to resolve disputes in order to realize legal certainty and maintain social order in a culture.
\end{abstract}

Keywords : Dispute Resolution; Land Reform; Non-litigation Process; Legal Certainty.

\section{INTRODUCTION}

Land is one of the main sources for the survival and livelihood of the Indonesian people, which is a gift from the Creator, namely Allah SWT. The philosophy of the Indonesian people wants to achieve an idealist that will seek land for the greatest achievement for the prosperity of the people who are divided fairly and evenly. ${ }^{1}$ Land is a very important factor in the life of a community, especially for the people of Indonesia where most of the population depends on land. In addition, land has a very important role in the life of the Indonesian people or in the implementation of national development which is held as a continuing effort to create a just and prosperous society based on Pancasila and the 1945 Constitution².

\footnotetext{
${ }^{1}$ Harsono, Boedi. (2002). Menuju Penyempurnaan Hukum Tanah Nasional dalam Hubungannya dengan TAP MPR RI IX/MPR/2001. Jakarta: Universitas Trisakti, p. 4.

${ }^{2}$ The 1945 Constitution of the Republic of Indonesia.
} 
Relating to creating a just and prosperous society, a society is inseparable from population growth in a city/district. While the high growth of urban population and the increasing development of land, the demand for land also increases, while the land supply is very limited. This situation results in higher land prices and in certain areas it is increasingly difficult to obtain land. This often leads to land disputes, both the control and ownership of land between community groups, between communities and companies, both private and state-owned corporation (BUMN), and between communities and the government.

Land will be cultivated or used for meeting real needs. In this connection, the provision, designation, control, use, and maintenance need to be regulated. In order to guarantee legal certainty by continuing to provide legal protection for many people while maintaining the sustainability of their ability to support sustainable development. ${ }^{3}$ Considering the importance of land for human survival, the legal provisions governing land issues are urgently needed as stated by Wirjono Projodikoro: ${ }^{4}$

"The existence of community needs for a rule of law certainty to the land in such a way, that every owner of the land-how much can be guaranteed in defending their property against interference from other parties".

Because of this, on September 24 1960, Law No. 5 of 1960 concerning Basic Regulations on Agrarian Principles (UUPA) was enacted. ${ }^{5}$ The UUPA fundamentally changed the land law that prevailed in Indonesia at that time. These changes include changing the law that prevailed before the UUPA, relating to customary law is the law that applies to the majority of Indonesia's population. ${ }^{6}$ Thus after the entry into force of the UUPA, the law applicable to earth, water and space is a national agrarian law. ${ }^{7}$ UUPA has brought the Indonesian people into unity in the field of agrarian law. If it is read carefully, the contents of the UUPA contain the basic points and still require the existence of laws and regulations which are implementing regulations.

The constitutional basis UUPA is based on Article 33 paragraph (3) of The 1945 Constitution. The fourth amendment, which states that, "The earth and water and natural resources contained therein are controlled by the state and used as much as possible the prosperity of the people", implies that each citizen have the right to enjoy the wealth and prosperity of the people is the goal to be achieved by Article 33 paragraph (3) of The 1945 Constitution Fourth Amendment. ${ }^{8}$

\footnotetext{
${ }^{3}$ Harsono, Boedi. (2002). Op. Cit., p. 5.

${ }^{4}$ Prodjodikoro, R. Wirjono. (1974). Bunga Rampai Hukum: Karangan Tersebar. Jakarta: PT. Ichtiar Baru Van Hoeve, p. 170.

${ }^{5}$ The Purpose of the Law of the Republic of Indonesia Number 5 of 1960 concerning Basic Regulations on Agrarian Principles. State Gazette of the Republic of Indonesia, Number 104 of 1960. Supplement to the State Gazette of the Republic of Indonesia, Number 2043.

${ }^{6}$ Revocation is because the old legislation does not comply with the principles used. D., Moh. Mahfud M. (1998). Politik Hukum di Indonesia. Jakarta: LP3ES, pp. 178 - 179.

${ }^{7}$ Soerodjo, Irawan. (2003). Kepastian Hukum Hak atas Tanah di Indonesia. Surabaya: Arkola, p. 3.

${ }^{8}$ Article 2 Paragraph (1) of Law No. 5 of 1960.
} 
The Elucidation of the UUPA emphasizes that the meaning of "mastered" in this article does not mean "owned" but rather is understanding; which gives authority to the state, as the power organization of the Indonesian nation, at the highest level to:

1. Arranging and carrying out the designation, use, supply and maintenance of earth, water and space;

2. Determine and regulate legal relations between people and earth, water and space;

3. Determine and regulate the legal relationship between people and legal actions regarding earth, water and space.

Right to control from the state referred to in Article 2 paragraph (1) of the UUPA shall be the state having the power to regulate lands that have been owned by a person or legal entity or free lands that have not been owned by a person or legal entity will be directly controlled by the state.

The state's right to control cannot be transferred to another party. Granting the right to state land does not mean that the state relinquishes the right of control over the said land. The land is still under state control. The state does not relinquish its authority regulated in Article 2 of the UUPA, on the land concerned. However, the state's authority over lands that have been granted with some rights to another party is limited, until there is a limit of authority which is the content of the given rights. The boundary must be respected by the state. Limitation of state power is a limitation held by the state for itself as a rule of law to not interfere with the control and use of land that has been granted with some rights to a person or legal entity. ${ }^{9}$

On the basis of the state's right to control land in the UUPA, furthermore regulates various types of land rights granted to individuals and legal entities. The state grants certain types of land rights to individuals or legal entities. Rights holders are charged with the obligation to register their land rights in order to achieve legal certainty. The UUPA and its implementing regulations provide a guarantee of legal certainty over land rights in all regions of Indonesia.

The Decree of the MPR RI No. IX/MPR/2001 ${ }^{10}$ states that agrarian reform is needed which includes a continuous process relating to the restructuring of mastery, research, use and utilization of agrarian resources, carried out in in order to achieve legal certainty and protection as well as justice and prosperity for all Indonesian people. ${ }^{11}$

For legal certainty, one of the efforts taken is through recording. Systematic recording of land and land rights is important both for the state administration and for the planning and development of the use of the land itself and for legal certainty in the transfer, transfer or assignment of land rights. ${ }^{12}$

\footnotetext{
${ }^{9}$ Harsono, Boedi. (1997). Hukum Agraria Indonesia: Sejarah Pembentukan Undang-Undang Pokok Agraria, Isi dan Pelaksanaannya. Jakarta: Djambatan, p. 243.

${ }^{10}$ The Decree of The People's Consultative Assembly of the Republic of Indonesia Number IX/MPR/2001 concerning Agrarian Reform and Natural Resource Management.

${ }^{11}$ Harsono, Boedi. (1997). Loc. Cit.

${ }^{12}$ Soerodjo, Irawan. (2003). Op. Cit., p. 26.
} 
Carrying out land registration as mandated by Article 19 paragraph (1) of the UUPA and Government Regulation No. 24 of $1997^{13}$ as an implementing regulation means that landowners receive protection and guarantee of legal certainty over land that has been registered and has strong evidence in the form of a certificate. This means it can reduce the occurrence of land disputes.

UUPA requires the registration of land in order to guarantee legal certainty. Land registration is further regulated by Government Regulation No. 10 of $1961^{14}$ which has been perfected by Government Regulation No. 24 of 1997 concerning Land Registration throughout Indonesia.

Government Regulation No. 24 of 1997 which enhances Government Regulation No. 10 of 1961 retains the purpose and system used in the UUPA, namely that land registration is carried out in order to provide legal certainty in the land sector. In addition, the land registration system does not adhere to a pure negative system, but which contains positive elements. as stated in Article 19 Paragraph (2) letter c, Article 23 Paragraph (2), Article 32 Paragraph (2) and Article 38 Paragraph (2) of the UUPA. Land registration is carried out in two ways, first systematically covering an area of one village or a part of which is mainly carried out on the initiative of the Government. Second, sporadically, namely the registration of parcels of land at the request of the holder or recipient of the relevant rights individually or in bulk. ${ }^{15}$

On the basis of the state's right to control, the government has the obligation to carry out land registration throughout the territory of the Republic of Indonesia in accordance with the UUPA which is individualistic religious communalistic. Besides aiming to protect land, the UUPA also regulates the legal relationship to land rights through the transfer of certificates as proof of land rights for holders. ${ }^{16}$ Government Regulation No. 24 of 1997 requires landowners to immediately register their lands because the certificate has the power of proof and certainty of land rights.

Meanwhile, from 1960 to 2004 land in Indonesia which had been recorded there were 84 million plots of land, which had been registered as many as 29 million plots of land, with details: ${ }^{17}$

1. Between 1960 and 1988,11 to 12 million parcels of land had been registered;

2. From 1988 to 2004 , there were 16.5 million to 17 million land parcels registered.

\footnotetext{
${ }^{13}$ Government Regulation of the Republic of Indonesia Number 24 of 1997 concerning Land Registration. State Gazette of the Republic of Indonesia, Number 59 of 1997. Supplement to the State Gazette of the Republic of Indonesia, Number 3696.

${ }^{14}$ Government Regulation of the Republic of Indonesia Number 10 of 1961 concerning Land Registration. State Gazette of the Republic of Indonesia, Number 28 of 1961. Supplement to the State Gazette of the Republic of Indonesia, Number 2171.

${ }^{15}$ Parlindungan, A. P. (1999). Pendaftaran Tanah di Indonesia. Bandung: CV. Mandar Maju, pp. 5 - 6.

${ }^{16}$ Chandra, S. (2005). Sertifikat Kepemilikan Hak Atas Tanah: Persyaratan Permohonan di Kantor Pertanahan. Jakarta: PT. Gramedia Widiasarana, p. 13.

${ }^{17} B P N$. (2004, Oktober). Pelatihan Pendidikan Teknis Pejabat Pembuat Akta Tanah (Diklat PPAT). Puncak Ciloto: Kementerian Agraria dan Tata Ruang/Badan Pertanahan Nasional, p. 1.
} 
In granting a certificate to a land owner with the principle of legal certainty, it creates a problem if the certificate as proof of land rights can still be claimed, because the truth of the data in the certificate can still be sued by the true land owner to the general court. The government in this case uses a negative system, because land registration in Indonesia has not been completed, as well the administration of land data in the local land office, such as the sub-district offices and the ranks of the relevant agencies have not been well recorded. This is expected because the data written in the certificate is incorrect or does not match the facts. ${ }^{18}$

Accordingly, land disputes arise and originate from complaints from one party, namely individuals, groups or legal entities regarding objections or demands for the use, control of land rights. Complaint means the submission of information or reports from parties who feel that their rights to their land are harmed, to other parties deemed authorized with the intention of obtaining a settlement either through law enforcement in court (litigation) or outside court (non-litigation).

Land disputes have increased from year to year ${ }^{19}$ which continued from independence, the Old Order, and the New Order until the current reform order. Land disputes can be purely a land ownership dispute for parties who feel they own land, but land disputes can also arise from efforts by land speculators to hamper development.

The phenomenon of land disputes has been critically responded to by several legal practitioners. Paulus Effendi Lotulung stated that since the State Administrative Court and the Administrative High Court were established, the cases that have been accepted are mostly land matters. accordingly, the statement of the National Commission on Human Rights (KOMNAS HAM) that since its inception in 1994 the complaints that have come in are dominated by land issues. At the cassation level in 2001 there were 4,048 cases of civil cassation. Of that number, around $51.06 \%$ or as many as 2066 cases were land disputes. Meanwhile, the National Ombudsman Commission notes that land issues are ranked fifth out of complaints received, while the Agrarian Reform Commission's data base records around 1,753 land dispute cases. ${ }^{20}$

According to the provisions of Article 16 of Law No. 4 of $2004^{21}$ which has been perfected by the Law No. 48 of $2009^{22}$ concerning Judicial Power, judges may not reject a case. This provision eventually led to many lawsuits over the ownership of certified land, which was followed by confiscation of land ownership, the party that won the case could not carry out the decision because of resistance from community members.

\footnotetext{
${ }^{18}$ Vide Decision of District Court of Surabaya Number 338/PDT.G/2007/PN.SBY.

${ }^{19}$ Sakti, Trie. (2006). Suatu Konsep Pemikiran Peradilan Pertanahan. Jurnal IImiah Hasil-Hasil Penelitian Pertanahan, Badan Pertanahan Nasional, 7(2), p. 1.

${ }^{20} \mathrm{lbid}$.

${ }^{21}$ Law of the Republic of Indonesia Number 4 of 2004 concerning Judicial Power. State Gazette of the Republic of Indonesia, Number 8 of 2004. Supplement to the State Gazette of the Republic of Indonesia, Number 4358.

${ }^{22}$ Law of the Republic of Indonesia Number 48 of 2009 concerning Judicial Power. State Gazette of the Republic of Indonesia, Number 157 of 2009. Supplement to the State Gazette of the Republic of Indonesia, Number 5076.
} 
In addition, land dispute decisions issued by judicial institutions are not consistent and there is no unity of understanding of the concepts of land law, poor administration, data on land and decisions, no grouping of land status that is integrated from Relevant institutions, lack of knowledge of judges, and lack of data on previous decisions relating to land have caused decisions made by the court to be useless, instead creating new problems which have increasingly become the cause of land disputes. ${ }^{23}$

This provision does not reduce the principle of providing balanced protection, both to those who own land and are controlled and used as appropriate and to those who acquire and control it in good faith, by him in order to provide legal certainty to holders of certified land rights, registration organizers Land needs support from several groups, in addition to the government as well as from all walks of life, and in particular the support of land rights holders. Legal certainty for certified ownership of land needs to be done in-depth and comprehensive research by developing various patterns in realizing legal certainty, specifically the process of resolving land disputes should be sought a theoretical conception in efforts to develop law and improve prosperity and welfare for landowners, so as to provide legal certainty for certified landowners and to avoid future land disputes.

\section{METHOD}

This descriptive study provides a description of the actual problem based on the facts that arise, the research methods used in accordance with the formulation of the problem that is the focus of this study. This type of research is juridical normative legal research that takes material derived from the literature contained in a variety of legal science libraries. Normative research which is the main research in this study is in accordance with the characteristics of typical legal science, so that the study material comes from the legal research library which is an academic scientific work. Normative juridical research uses primary legal materials, secondary legal materials, and tertiary legal materials. Departing from a legal issue that was examined by the author, then the technique of analyzing legal materials that have been summarized in full by the author, then described with qualitative analysis.

\section{ANALYSIS AND DISCUSSION}

Analysis and discussion contains a description of the results of research on issues that are the focus of research or the results of studies with efforts to develop the concept of legal development. The mandate of the 1945 Constitution in addition to being a political constitution can also be referred to as an economic constitution. One of the important

\footnotetext{
${ }^{23}$ Chandra, Teddy. (2007). Sengketa Tanah Meruya Akibat Carut Marut Sistem Pendaftaran Tanah di Indonesia Dikaitkan Penyelesaian Sengketa Tanah. Majalah Poros, $5^{\text {th }}$ Edition, p. 53.
} 
characteristics as an economic constitution is that the 1945 Constitution contains the idea of a welfare state. ${ }^{24}$

Study of the concept of socioeconomic state, the state is obliged to bring prosperity to all people, both social and economic welfare. The state aims to prosper its people and is demanded to provide the best and broadest possible service to its people. The originator of the flow of utilitarianism ${ }^{25}$ states that the law made by the ruler must be aimed at realizing the greatest happiness for as many people as possible (the greatest happiness of the greatest number), then the purpose of the legislation made by the ruler must be able to produce happiness for the community. For this reason, the authorities with their laws and regulations must try to achieve four objectives, that is:

1. to provide a living;

2. to provide abundant food;

3. to provide protection;

4. to achieve equality.

Article 33 of the 1945 Constitution has also accommodated the need for development in the economic sector and for the first time it originated from the concept formulated by Mohammad Hatta as the basis for economic politics in the context of further economic development. ${ }^{26}$ The formulation was carried out with consideration of changes in Europe (especially in the Netherlands), liberal capitalism gradually vanished and the flow of neo-mercantilism grew stronger. Based on this, Mohammad Hatta argued that the global economy that occurred in the third world at that time tended to develop and far from individualism, which would otherwise be closer to collectivism based on the principle of shared prosperity. Mohammad Hatta further said:

"Indeed collectivism is in accordance with the ideals of life in Indonesia, since long ago the Indonesian people, as well as other Asian societies based on collectivism, which is known as the basis of mutual help".

It is this spirit of family and mutual cooperation that animates the formulation of the idea of managing people's economic resources in the 1945 Constitution. The Indonesian economy is structured as a joint effort based on the principle of kinship. The important branches of production that control the lives of many people are controlled by the state. Only the branches of production that are not important or do not control the lives of many people can be developed outside of state power. All wealth controlled by the country, whether in the form of earth, water, and natural resources contained therein must be used for the greatest prosperity of the people.

\footnotetext{
${ }^{24}$ Asshiddiqie, Jimly. (1998, 13 Juni). Undang-Undang Dasar 1945: Konstitusi Negara Kesejahteraan dan Realitas Masa Depan. In Pidato Pengukuhan Jabatan Guru Besar Tetap Madya. Jakarta: Fakultas Hukum, Universitas Indonesia, p. 1.

${ }^{25}$ Ali, Achmad. (2002). Menguak Tabir Hukum: Suatu Kajian Filosofis dan Sosiologis. Jakarta: Gunung Agung, pp. $267-268$.

${ }^{26}$ Swasono, Sri Edi (Ed.) (1985). Sistem Ekonomi dan Demokrasi Ekonomi. Jakarta: UI Press, p. 1.
} 
Being controlled by the state does not mean that the state itself is an entrepreneur, a businessman but a power of the state to make rules for economic smoothness, regulations which prohibit exploitation of the weak by capital. ${ }^{27}$ The purpose of state control over the sources of the country's economy is to maximize the prosperity of the people. The state is obliged to: 28

a) all forms of utilization (earth and water) and the results obtained (natural resources) must significantly increase the prosperity and welfare of the community;

b) protect and guarantee the rights of the people contained in or on the earth, water and certain natural resources that can be directly or directly enjoyed by the people;

c) prevent all actions from any party that will cause people to not have the opportunity or will lose their rights to enjoy natural wealth.

In connection with a system of economic management that is in favor of the people, Friedmann identified four functions of the state in the economic field, namely:

1) as a provider (guarantor) of people's welfare:29

2) as a regulator (regulator);

3) as an entrepreneur (entrepreneur) or run certain sectors through state-owned corporation (BUMN); and

4) as umpire (supervisor, referee) to formulate fair standards regarding the performance of the economic sector.

Referring to the concept of socio-economic state such as the Indonesian nation, the state is obliged to bring prosperity to all people, both social and economic welfare. The state aims to prosper its people and is demanded to provide the best and broadest possible service to its people.

In paragraph IV of the Preamble to the 1945 Constitution explicitly stated the purpose of the country, namely:

"Protect all the people of Indonesia and all Indonesian blood and to promote public welfare, educate the nation's life and participate in carrying out world order based on independence, lasting peace and social justice ..."

Philosophical formation of the state or government and the organizing apparatus, among others, is aimed at preventing and avoiding, at least reducing disputes that occur within the community, ${ }^{30}$ by it can be interpreted that the function of the state and government is to provide protection for its citizens, both in the political and socio-economic fields. There is an influence on the task of government with a view to guaranteeing the

${ }^{27}$ Hatta, Mohammad. (1977). Penjabaran Pasal 33 UUD 1945. Jakarta: Mutiara, p. 28.

${ }^{28}$ Manan, Bagir. (1999). Beberapa Catatan Atas Rancangan Undang-Undang tentang Minyak dan Gas Bumi. In Makalah Fakultas Hukum. Universitas Padjadjaran: Bandung, pp. $1-2$.

${ }^{29}$ Abrar. (1995). Hak Penguasaan Negara Atas Pertambangan Berdasarkan Undang-Undang Dasar 1945. (Doctoral Dissertation), Universitas Padjadjaran, Bandung, p. 26. 225.

${ }^{30}$ Kusnardi, Moh., \& Saragih, Bintan Regen. (1988). Ilmu Negara. Jakarta: Gaya Media Pratama, pp. 210 - 
public interest, so that the field of work includes various aspects such as public health, education, housing, land distribution and so on, ${ }^{31}$ and is obliged to pay attention to general principles of good governance, that is: ${ }^{32}$

"legal certainty, balance, equality of decisions, principle of accuracy, principle of separation of authority, justice, honesty, nullifying the consequences of null and void decisions, protection, wisdom and the implementation of public interests".

Development in the broadest sense includes all aspects of people's lives, one of which is law and order enforcement which is an absolute prerequisite for efforts to establish a peaceful and prosperous Indonesia, it is natural that Hans Kelsen sees law as something that should (das sollen), so that apart from social reality (das sein). Everyone must obey the law as a state's will. The law is nothing but a rule of order that requires people to obey as they should. ${ }^{33}$

If the law is enforced and order is realized, the certainty of security, peace and harmony can be realized. No law enforcement and order will hamper the achievement of people who try and work well to meet their daily needs. This means that the law must be an instrument to direct society towards the desired goal. Legal reform efforts should begin with a conception that law is a means of community renewal, ${ }^{34}$ one of them carries out the function of law as an applied science to develop various procedures for legal certainty, as a consistent step in legal development.

Law as an important means of maintaining order must be developed and fostered, so as to provide space for this change. Not the other way is hindering renewal efforts because they simply want to maintain old values. In fact, the law must come forward showing direction and giving way to renewal. ${ }^{35}$ Good law is a law that is in accordance with the law that lives in society. This shows that there is a compromise between the written law as the needs of the legal community for the sake of legal certainty and living law in the community (living law) as an expression of appreciation for the important role of the community in the formation and orientation of the law. ${ }^{36}$

Legal development (not just legal renewal) in this sense is the harmonization of values to cope with what is missing, broken or wrong, lack, congestion and deterioration or deterioration. Whereas "law enforcement" should be interpreted as tackling these matters p. 45.

${ }^{31}$ Marbun, S. F., \& D., Moh. Mahfud M. (1987). Pokok-Pokok Hukum Administrasi Negara. Yogyakarta: Liberty,

${ }^{32}$ Purbopranoto, Kuntjoro. (1981). Beberapa Catatan Hukum Tata Pemerintahan dan Peradilan Administrasi Negara. Bandung: PT. Alumni, 1981, pp. 29 - 30.

${ }^{33}$ Rasjidi, Lili. (2001). Dasar-Dasar Filsafat dan Teori Hukum. Bandung: PT. Citra Aditya Bakti.

${ }^{34}$ Kusumaatmadja, Mochtar. (1976). Hukum, Masyarakat dan Pembinaan Hukum Nasional: Suatu Uraian tentang Landasan Pikiran, Pola dan Mekanisme Pembaharuan Hukum di Indonesia. Bandung: Fakultas Hukum, Universitas Padjadjaran, pp. 8 - 9.

${ }^{35}$ Kusumaatmadja, Mochtar. (2002). Konsep-Konsep Hukum dalam Pembangunan (Otje Salman \& Eddy Damian Eds.). Bandung: PT. Alumni, p. 74. p. 22

${ }^{36}$ Idham, H. (2004). Konsolidasi Tanah Perkotaan dalam Perspektif Otonomi Daerah. Bandung: PT. Alumni, 
based on a harmonious value interwoven system to maintain (law as a tool of social control) and improve (law as a tool of social engineering) peace of human life. ${ }^{37}$

Law enforcement implies that there are three elements which must always receive attention, namely: justice, usefulness or usufruct and legal certainty. ${ }^{38}$ The large number of land disputes is caused by the lack of awareness and understanding of the community towards the laws and other legal regulations in the land sector. Coordination between agencies related to land issues, different perceptions of notions and regulations in the land sector need to be improved, so as not to cause uncertainty. ${ }^{39}$

The political objectives of law not only guarantee justice, but also create legal certainty. Legal certainty is closely related to legal effectiveness, because legal certainty guarantees will arise, if the state has adequate means to implement existing regulations. ${ }^{40}$ Land certificate as the final product of land registration as instructed by UUPA and Government Regulations No. 24 of 1997, has binded the officials of the National Land Agency (BPN) to issue certificates as a strong proof of land ownership. ${ }^{41}$

The UUPA has laid the groundwork for providing legal certainty regarding land rights. Legal certainty regarding land rights is legal certainty aimed at the land sector, specifically regarding ownership and/or control. The existence of legal certainty over land rights will provide clarity about:

1. certainty regarding the person or legal entity that is the holder of land rights, also known as certainty regarding the subject of rights;

2. certainty regarding the location, boundaries, extent, whether or not burdened with other rights, and so on, in other words also referred to as certainty about the object of rights.

Based on the provisions of Article 19 Paragraph (1) it is intended that the certificate is to guarantee legal certainty and in paragraph (2) letter $c$ the certificate is a strong means of proof, that is: ${ }^{42}$

"whoever submits events in his name on the basis of a right, is obliged to prove those events, on the other hand whoever submits events to rebut the rights of others, is also required to prove those events."

Theories about the burden of proof that can be used as a guideline, that is: ${ }^{43}$

\footnotetext{
BP. Cipta Jaya, p. 16.

${ }^{38}$ Kusumaatmadja, Mochtar. (1970). Fungsi dan Perkembangan Hukum dalam Pembangunan Nasional. Bandung: Fakultas Hukum, Universitas Padjadjaran, p. 2.

${ }^{39}$ Elyana. (1997, 6 Agustus). Peran Pengadilan dalam Pelaksanaan Peraturan Pemerintah Nomor 24 Tahun 1997. In Seminar Kebijaksanaan Baru di Bidang Pertanahan, Dampak dan Peluang Bagi Bisnis Properti dan Perbankan. Jakarta.

${ }^{40}$ Huijbers, Theo. (1995). Filsafat Hukum dalam Lintasan Sejarah. Yogyakarta: PT. Kanisius, p. 119.

${ }^{41}$ Sutedi, Adrian. (2006). Op. Cit., p. 17.

${ }^{42}$ Subekti, Raden. (1985). Pokok-Pokok Hukum Perdata. Jakarta: PT. Intermasa, p. 177.

${ }^{43}$ Pitlo, A. (1978). Pembuktian dan Daluwarsa: Menurut Kitab Undang-Undang Hukum Perdata Belanda (M. Isa Arief, Trans.). Jakarta: PT. Intermasa, p. 45.
} 
a. Theory of proof which is merely reinforcing (bloot affirmatief), namely: for those who say something must prove and who does not deny or deny it;

b. Subjective theory which states that a civil process is the implementation of subjective law or aims to maintain subjective law which means that those who express or claim to have rights must prove;

c. An objective theory which states that filing a lawsuit means the litigant asks the court that the judge applies the provisions of objective law to the events submitted. Therefore the litigant must prove and judge the task of applying objective law to the incident;

d. Public theory which gives broader authority to judges to seek the truth by prioritizing the public interest. ${ }^{44}$

Article 1865 of the Civil Code (Civil Code) and Article 163 of the Herzien Indonesisch Reglement (HIR) which states: ${ }^{45}$

"Everyone argues that he has a right, or to assert his own rights or to deny someone else's rights, point to an event, is obliged to prove the existence of that right or event."

Article 164 Herzien Indonesisch Reglement (HIR) juncto Article 1866 of the Civil Code (Civil Code) states: ${ }^{46}$

"So what is called evidence, namely: documentary evidence, witness evidence, evidence of suspicion, confession and oath"

All of these evidences in a court case are considered important, but because the HIR adheres to the principle of formal proof, it is seen here that the written evidence which is only written evidence is considered important in the proof.

The law of proof provides clues as to how the judge can establish the truth. In evaluating the strength of the evidence, several systems or theories of proof must be known, that is: 47

a. Subjective theory

Whoever demands a subjective right must prove the existence of that right. And those who oppose that right must prove the absence of that right. So the litigant must prove the facts that give rise to that right and the defendant must prove the facts that negate that right.

b. Objective theory

The litigant must prove the existence of facts which, by objective law, are due to the legal consequences of the facts. Instead the defendant must prove the existence of facts which in objective law are deviations from the things raised by the litigant.

${ }^{44}$ Prodjohamidjojo, Martiman. (1997). Hukum Pembuktian: Dalam Sengketa Tata Usaha Negara (UU No. 5 Tahun 1986, LN No. 77). Jakarta: PT. Pradnya Paramita, p. 42.

${ }^{45}$ Subekti, Raden, \& Tjitrosudibio, R. (1995). Kitab Undang-Undang Hukum Perdata. Jakarta: PT. Pradnya Paramita, p. 475.

${ }^{46}$ Tresna, R. (1995). Komentar HIR. Jakarta: PT. Pradnya Paramita, p. 141.

${ }^{47}$ Afandi, Ali. (1986). Hukum Waris, Hukum Keluarga, Hukum Pembuktian: Menurut Kitab Undang-Undang Hukum Perdata (BW). Jakarta: PT. Bina Aksara, pp. $196-197$. 


\section{c. Propriety theory}

The judge makes the distribution of evidence based on justice. In a dispute the litigant and the defendant have the same position and the judge divides the burden of proof according to his own sense of justice. The judge can oblige the party with the burden of proof that is the easiest to provide proof. The certificate as a strong means of proof in the proof of ownership, the certificate guarantees legal certainty regarding the person who holds the ownership rights to the land. Legal certainty regarding the location of the land, the boundaries and area of a parcel of land, and legal certainty regarding the rights to his land. Strictly speaking, for legal certainty, protection can be given to people whose names are listed in the certificate from interference from other parties and to avoid disputes with other parties. The guarantee of legal certainty is not only addressed to the person whose name is listed on the certificate as the owner of the land, but also is a government policy in creating an orderly administration of land which places an obligation on the government to carry out registration of lands throughout Indonesia.

Efforts to implement and enforce law in Indonesia are divided into two dispute resolutions, namely in the court and outside the court. Non-dispute resolution arises based on the needs of the community that requires solving problems with easy and fast procedures and to achieve a legal problem or dispute resolution must be built a new paradigm, namely changing the paradigm to adjudicate into a paradigm of solving problems or legal disputes. This new paradigm covers two main strategies ${ }^{48}$, that is:

a. Revitalization of functions to reconcile parties facing legal disputes. This function is mainly related to legal disputes that are not criminal cases, in accordance with existing provisions, the judge is obliged to bring the two parties to the dispute to have a discussion that produces a win-win solution;

b. Revitalizing social institutions by providing stronger foundations for the development of alternative dispute resolution (ADR);

c. Rearranging the procedure for the settlement of a case to be more efficient, effective, productive and reflects the integration of the system among elements of law enforcement by detailing the division of tasks and authority among legal officers. The principle of an integrated justice system in criminal cases (integrated criminal judicial system), is not enough to regulate the coordination relationship between law enforcement;

d. Reorganize litigation rights which cause a protracted settlement, and contain various potential "permanent" conflicts between litigants.

Non-litigation process is an institution for dispute resolution or dissent through a procedure agreed by the parties, namely settlement outside the court by means of consultation, negotiation, mediation, conciliation, or expert judgment.

${ }^{48}$ Manan, Bagir. (2005). Sistem Peradilan Berwibawa: Suatu Pencarian. Yogyakarta: UII Press, pp. 25 - 26. 
One alternative to dispute resolution that can be carried out outside the court and conducted in a court conducted in Indonesia is Mediation. Law No. 30 of $1999^{49}$ and Supreme Court Regulation No. 1 of $2008^{50}$, considering that mediation is the settlement of disputes through a negotiation process of the parties with the assistance of the mediator, ${ }^{51}$ to find a win-win solution.

Along with the times and the human need for speedy resolution of a dispute, making dispute resolution in court is considered detrimental because it requires a long time and expensive costs. Based on this, it raises a breakthrough that can resolve cases quickly and at low cost. Alternative dispute resolution is usually used for disputes in the economic field.

Not only does the alternative dispute resolution have the advantage of being able to settle a dispute in a short time and low cost, but it has a very risky weakness that the results of this alternative dispute resolution must be registered at the District Court within 30 (days) in accordance with Article 6 paragraph (7) of Law No. 30 of 1999.

If the registration of alternative dispute resolution results is received by the District Court within 30 (thirty) days it will not be an issue, but if the results of the dispute resolution agreed by the disputing parties are denied registration by the District Court or beyond the time period which has been determined, it will lead to a longer dispute resolution process. Alternative land dispute resolution institutions (Alternative Dispute Resolution) are mediation institutions that can be used to resolve problems in the form of an agreement between the parties to the problem in question.

Along with the times and the human need for speedy resolution of a dispute, making dispute resolution in court is considered detrimental because it requires a long time and expensive costs. Based on this, it raises a breakthrough that can solve cases quickly and at low cost. Alternative dispute resolution is usually used for disputes in the economic field. Some of the advantages of Alternative Dispute Resolution are:

a. Complete quickly;

b. The desire of the parties to the dispute without coercion;

c. Honorable and closed;

d. Confidentiality of both parties to the dispute is guaranteed (not published);

e. Expert opinions in their fields;

f. Flexibility;

g. Maintaining good relations between parties to the dispute;

h. Time and cost savings.

${ }^{49}$ Law of the Republic of Indonesia Number 30 of 1999 concerning Arbitration and Alternative Dispute Resolution. State Gazette of the Republic of Indonesia, Number 138 of 1999. Supplement to the State Gazette of the Republic of Indonesia, Number 3872.

${ }^{50}$ Supreme Court Regulation of the Republic of Indonesia Number 1 of 2008 concerning Mediation Procedures in the Court.

${ }^{51}$ Sutadi, Mariana. (2004, 17 - 18 Februari). Pendayagunaan Perdamaian Menurut Pasal 130 HIR/154 R.Bg dan Potensinya dalam Mewujudkan Keadilan yang Cepat, Sederhana dan Biaya Ringan. Paper presented at the Mediasi dan Court Annexed Mediation, Jakarta: Kerjasama antara Mahkamah Agung RI dan Pusat Pengkajian Hukum, p. 30. 
Non-litigation process, among others, to carry out resolutions without the involvement of a third party, conciliation that is family friendly (mediation), namely mediation, with the assistance of a third party who is neutral in the effort to negotiate the settlement of the accident, the third party is not authorized to make decisions.

The handling of land disputes can use settlement institutions based on authority as referred to in Government Regulations No. 24 of 1997, PMNA/Head of BPN No. 9 of $1999^{52}$ and PMNA/Head of BPN No. 1 of $1999^{53}$, mediation institutions, negotiation institutions and Alternative Dispute Resolution agencies or alternative dispute resolution (ADR/APS). In dealing with these disputes it is possible to coordinate between stakeholders and consultations with relevant agencies.

The potential to conduct a case in an alternative dispute resolution process through a mediation, arbitration process involving the BPN, the local government, community leaders, the affected community. Plaintiffs and defendants. The APS process reflects an easy, fast and inexpensive process so that it can resolve protracted land disputes at the court level. APS Decisions can be directly carried out by the land administration (BPN) without having to wait for a court decision because from the beginning all parties who litigated, the BPN, local government and community leaders have been involved in the APS process.

The author's argument for the settlement of the land must involve not only the plaintiff/defendant but the land administration operator, the local government and community leaders. This problem has been answered if the APS process which is a legacy of Indonesia's ancestors that prioritizes the interests of the wider community rather than personal or group interests in resolving land issues. So that all parties sit together and equal/no party wins or loses (win-win lose) and realizes that the land he occupies now is a legacy of ancestors that must be preserved and preserved for the benefit of the people and the prosperity of the community as much as possible.

\section{CONCLUSION}

Negative land administration systems provide relative legal certainty for landowners as long as land ownership evidence is not proven otherwise. The administration process of issuing certificates through measurements, announcements, and examinations carried out by the national land office (BPN), Subdistricts and Villages is limited to procedural without a judicial review on the basis of normative juridical land ownership and recording of inaccurate transfer of rights causes errors in writing data on land and rights holders in the certificate can canceled. Land Dispute is a multi-dimensional and complex form of dispute,

${ }^{52}$ Regulation of the Minister of State Agrarian/Head of the National Land Agency of the Republic of Indonesia Number 9 of 1999 concerning Procedures for Granting and Cancellation of State Land Rights and Management Rights.

${ }^{53}$ Regulation of the Minister of State Agrarian/Head of the National Land Agency of the Republic of Indonesia Number 1 of 1999 concerning Procedures for Handling Disputes. 
because it contains legal, economic, political, socio-cultural and security interests. The existence of land disputes illustrates the uncertainty of the competence of the judiciary's structure in handling land disputes that take years. Mediation and arbitration help the parties to the dispute reach an acceptable and favorable agreement.

\section{REFERENCE}

Abrar. (1995). Hak Penguasaan Negara Atas Pertambangan Berdasarkan Undang-Undang Dasar 1945. (Doctoral Dissertation), Universitas Padjadjaran, Bandung.

Afandi, Ali. (1986). Hukum Waris, Hukum Keluarga, Hukum Pembuktian: Menurut Kitab Undang-Undang Hukum Perdata (BW). Jakarta: PT. Bina Aksara.

Ali, Achmad. (2002). Menguak Tabir Hukum: Suatu Kajian Filosofis dan Sosiologis. Jakarta: Gunung Agung.

Asshiddiqie, Jimly. (1998, 13 Juni). Undang-Undang Dasar 1945: Konstitusi Negara Kesejahteraan dan Realitas Masa Depan. In Pidato Pengukuhan Jabatan Guru Besar Tetap Madya. Jakarta: Fakultas Hukum, Universitas Indonesia.

Aswari, A., Buana, A. P., \& Rezah, F. S. (2018). Harmonisasi Hukum Hak untuk Dilupakan bagi Koran Digital terhadap Calon Mahasiswa di Makassar. Kanun: Jurnal IImu Hukum, Universitas Syiah Kuala, 20(1), 39 - 62.

BPN. (2004, Oktober). Pelatihan Pendidikan Teknis Pejabat Pembuat Akta Tanah (Diklat PPAT). Puncak - Ciloto: Kementerian Agraria dan Tata Ruang/Badan Pertanahan Nasional.

Chandra, S. (2005). Sertifikat Kepemilikan Hak Atas Tanah: Persyaratan Permohonan di Kantor Pertanahan. Jakarta: PT. Gramedia Widiasarana.

Chandra, Teddy. (2007). Sengketa Tanah Meruya Akibat Carut Marut Sistem Pendaftaran Tanah di Indonesia Dikaitkan Penyelesaian Sengketa Tanah. Majalah Poros, $5^{\text {th }}$ Edition.

D., Moh. Mahfud M. (1998). Politik Hukum di Indonesia. Jakarta: LP3ES.

Decision of District Court of Surabaya Number 338/PDT.G/2007/PN.SBY.

Elyana. (1997, 6 Agustus). Peran Pengadilan dalam Pelaksanaan Peraturan Pemerintah Nomor 24 Tahun 1997. In Seminar Kebijaksanaan Baru di Bidang Pertanahan, Dampak dan Peluang Bagi Bisnis Properti dan Perbankan. Jakarta.

Government Regulation of the Republic of Indonesia Number 10 of 1961 concerning Land Registration. State Gazette of the Republic of Indonesia, Number 28 of 1961. Supplement to the State Gazette of the Republic of Indonesia, Number 2171. 
Government Regulation of the Republic of Indonesia Number 24 of 1997 concerning Land Registration. State Gazette of the Republic of Indonesia, Number 59 of 1997. Supplement to the State Gazette of the Republic of Indonesia, Number 3696.

Harsono, Boedi. (1997). Hukum Agraria Indonesia: Sejarah Pembentukan Undang-Undang Pokok Agraria, Isi dan Pelaksanaannya. Jakarta: Djambatan.

Harsono, Boedi. (2002). Menuju Penyempurnaan Hukum Tanah Nasional dalam Hubungannya dengan TAP MPR RI IX/MPR/2001. Jakarta: Universitas Trisakti.

Hatta, Mohammad. (1977). Penjabaran Pasal 33 UUD 1945. Jakarta: Mutiara.

Huijbers, Theo. (1995). Filsafat Hukum dalam Lintasan Sejarah. Yogyakarta: PT. Kanisius.

Idham, H. (2004). Konsolidasi Tanah Perkotaan dalam Perspektif Otonomi Daerah. Bandung: PT. Alumni.

Kusnardi, Moh., \& Saragih, Bintan Regen. (1988). Ilmu Negara. Jakarta: Gaya Media Pratama.

Kusumaatmadja, Mochtar. (1970). Fungsi dan Perkembangan Hukum dalam Pembangunan Nasional. Bandung: Fakultas Hukum, Universitas Padjadjaran.

Kusumaatmadja, Mochtar. (1976). Hukum, Masyarakat dan Pembinaan Hukum Nasional: Suatu Uraian tentang Landasan Pikiran, Pola dan Mekanisme Pembaharuan Hukum di Indonesia. Bandung: Fakultas Hukum, Universitas Padjadjaran.

Kusumaatmadja, Mochtar. (2002). Konsep-Konsep Hukum dalam Pembangunan (Otje Salman \& Eddy Damian Eds.). Bandung: PT. Alumni.

Law of the Republic of Indonesia Number 5 of 1960 concerning Basic Regulations on Agrarian Principles. State Gazette of the Republic of Indonesia, Number 104 of 1960. Supplement to the State Gazette of the Republic of Indonesia, Number 2043.

Law of the Republic of Indonesia Number 30 of 1999 concerning Arbitration and Alternative Dispute Resolution. State Gazette of the Republic of Indonesia, Number 138 of 1999. Supplement to the State Gazette of the Republic of Indonesia, Number 3872.

Law of the Republic of Indonesia Number 4 of 2004 concerning Judicial Power. State Gazette of the Republic of Indonesia, Number 8 of 2004. Supplement to the State Gazette of the Republic of Indonesia, Number 4358.

Law of the Republic of Indonesia Number 48 of 2009 concerning Judicial Power. State Gazette of the Republic of Indonesia, Number 157 of 2009. Supplement to the State Gazette of the Republic of Indonesia, Number 5076. 
Manan, Bagir. (1999). Beberapa Catatan Atas Rancangan Undang-Undang tentang Minyak dan Gas Bumi. In Makalah Fakultas Hukum. Universitas Padjadjaran: Bandung.

Manan, Bagir. (2005). Sistem Peradilan Berwibawa: Suatu Pencarian. Yogyakarta: UII Press.

Marbun, S. F., \& D., Moh. Mahfud M. (1987). Pokok-Pokok Hukum Administrasi Negara. Yogyakarta: Liberty.

Parlindungan, A. P. (1999). Pendaftaran Tanah di Indonesia. Bandung: CV. Mandar Maju.

Pitlo, A. (1978). Pembuktian dan Daluwarsa: Menurut Kitab Undang-Undang Hukum Perdata Belanda (M. Isa Arief, Trans.). Jakarta: PT. Intermasa.

Presidential Regulation of the Republic of Indonesia Number 63 of 2013 concerning National Land Agency of the Republic of Indonesia. State Gazette of the Republic of Indonesia, Number 155 of 2013.

Presidential Regulation of the Republic of Indonesia Number 20 of 2015 concerning National Land Agency. State Gazette of the Republic of Indonesia, Number 21 of 2015.

Prodjodikoro, R. Wirjono. (1974). Bunga Rampai Hukum: Karangan Tersebar. Jakarta: PT. Ichtiar Baru Van Hoeve.

Prodjohamidjojo, Martiman. (1997). Hukum Pembuktian: Dalam Sengketa Tata Usaha Negara (UU No. 5 Tahun 1986, LN No. 77). Jakarta: PT. Pradnya Paramita.

Purbopranoto, Kuntjoro. (1981). Beberapa Catatan Hukum Tata Pemerintahan dan Peradilan Administrasi Negara. Bandung: PT. Alumni.

Qamar, N., Syarif, M., Busthami, D. S., \& Rezah, F. S. (2016). Sosiologi Hukum (Sociology of Law). Jakarta: Mitra Wacana Media.

Rasjidi, Lili. (2001). Dasar-Dasar Filsafat dan Teori Hukum. Bandung: PT. Citra Aditya Bakti.

Regulation of the Minister of State Agrarian/Head of the National Land Agency of the Republic of Indonesia Number 1 of 1999 concerning Procedures for Handling Disputes.

Regulation of the Minister of State Agrarian/Head of the National Land Agency of the Republic of Indonesia Number 9 of 1999 concerning Procedures for Granting and Cancellation of State Land Rights and Management Rights.

Sakti, Trie. (2006). Suatu Konsep Pemikiran Peradilan Pertanahan. Jurnal IImiah HasilHasil Penelitian Pertanahan, Badan Pertanahan Nasional, 7(2). 
Volume 2, Issue 2, December $2019: 177-194$

Soerodjo, Irawan. (2003). Kepastian Hukum Hak atas Tanah di Indonesia. Surabaya:

Arkola.

Subekti, Raden, \& Tjitrosudibio, R. (1995). Kitab Undang-Undang Hukum Perdata. Jakarta: PT. Pradnya Paramita.

Subekti, Raden. (1985). Pokok-Pokok Hukum Perdata. Jakarta: PT. Intermasa.

Supreme Court Regulation of the Republic of Indonesia Number 1 of 2008 concerning Mediation Procedures in the Court.

Sutadi, Mariana. (2004, 17 - 18 Februari). Pendayagunaan Perdamaian Menurut Pasal 130 HIR/154 R.Bg dan Potensinya dalam Mewujudkan Keadilan yang Cepat, Sederhana dan Biaya Ringan. Paper presented at the Mediasi dan Court Annexed Mediation, Jakarta: Kerjasama antara Mahkamah Agung RI dan Pusat Pengkajian Hukum.

Sutedi, Adrian. (2006). Kekuatan Hukum Berlakunya Sertifikat sebagai Tanda Bukti Hak Atas Tanah. Jakarta: BP. Cipta Jaya.

Swasono, Sri Edi (Ed.) (1985). Sistem Ekonomi dan Demokrasi Ekonomi. Jakarta: UI Press.

The 1945 Constitution of the Republic of Indonesia.

The Decree of The People's Consultative Assembly of the Republic of Indonesia Number IX/MPR/2001 concerning Agrarian Reform and Natural Resource Management.

Tresna, R. (1995). Komentar HIR. Jakarta: PT. Pradnya Paramita. 